\title{
Intracellular Calcium Homeostasis in Human Primary Muscle Cells from Malignant Hyperthermia-susceptible and Normal Individuals \\ Effect of Overexpression of Recombinant Wild-type and Arg163Cys Mutated Ryanodine Receptors
}

\author{
Kathrin Censier, ${ }^{\star}$ Albert Urwyler, ${ }^{*}$ Francesco Zorzato, ${ }^{\ddagger}$ and Susan Treves ${ }^{\ddagger}$ \\ $*$ Department of Anaesthesiology and Research, Kantonsspital/University of Basel, 4031 Basel, Switzerland, and ${ }^{\ddagger}$ Department of \\ Experimental and Diagnostic Medicine, General Pathology Section, University of Ferrara, Via Borsari 46, 44100 Ferrara, Italy
}

\begin{abstract}
Malignant hyperthermia (MH) is a hypermetabolic disease triggered by volatile anesthetics and succinylcholine in genetically predisposed individuals. Nine point mutations in the skeletal muscle ryanodine receptor (RYR) gene have so far been identified and shown to correlate with the MH-susceptible phenotype, yet direct evidence linking abnormal $\mathrm{Ca}^{2+}$ homeostasis to mutations in the RYR1 cDNA has been obtained for few mutations. In this report, we show for the first time that cultured human skeletal muscle cells derived from MH-susceptible individuals exhibit a half-maximal halothane concentration causing an increase in intracellular $\mathrm{Ca}^{2+}$ concentration which is twofold lower than that of cells derived from MH-negative individuals. We also present evidence demonstrating that overexpression of wild-type RYR1 in cells obtained from MH-susceptible individuals does not restore the $\mathrm{MH}$-negative phenotype, as far as $\mathrm{Ca}^{2+}$ transients elicited by halothane are concerned; on the other hand, overexpression of a mutated RYR1 Arg163Cys $\mathrm{Ca}^{2+}$ channel in muscle cells obtained from MH-negative individuals conveys hypersensitivity to halothane. Finally, our results show that the resting $\mathrm{Ca}^{2+}$ concentration of cultured skeletal muscle cells from MH-negative and $\mathrm{MH}$-susceptible individuals is not significantly different. (J. Clin. Invest. 1998. 101:1233-1242.) Key words: $\mathrm{Ca}^{2+}$ channel • skeletal muscle $\bullet$ halothane $\bullet$ neuromuscular disorder $\bullet$ hypermetabolism
\end{abstract}

\section{Introduction}

Malignant hyperthermia $(\mathrm{MH})^{1}$ is an inherited pharmacogenetic muscle disorder triggered by halogenated anesthetic

\footnotetext{
Address correspondence to Susan Treves, Department of Experimental and Diagnostic Medicine, General Pathology Section, University of Ferrara, Via Borsari 46, 44100 Ferrara, Italy. Phone: 39-532291356; FAX: 39-532-247278; E-mail: zor@ifeuniv.unife.it

Received for publication 20 June 1997 and accepted in revised form 14 January 1998.
}

1. Abbreviations used in this paper: $\left[\mathrm{Ca}^{2+}\right]_{\mathrm{i}}$, intracellular $\mathrm{Ca}^{2+}$ concentration; IVCT, in vitro contracture test; $\mathrm{MH}$, malignant hyperthermia; MHN, MH-negative; MHS, MH-susceptible; RYR, ryanodine receptor; SR, sarcoplasmic reticulum.

J. Clin. Invest.

(c) The American Society for Clinical Investigation, Inc. 0021-9738/98/03/1233/10 \$2.00

Volume 101, Number 6, March 1998, 1233-1242

http://www.jci.org agents such as halothane, enflurane, isofluorane, desflurane, or sevoflurane and the depolarizing myorelaxant succinylcholine. An $\mathrm{MH}$ crisis is characterized by skeletal muscle rigidity, accelerated metabolism, and a rapid rise in body temperature; unless recognized immediately and treated, it is often fatal (1, 2). Initial studies in the molecular defect underlying this pathology indicated an abnormal regulation of the sarcoplasmic reticulum (SR) $\mathrm{Ca}^{2+}$ release mechanism (for a review, see reference 3 ). These results were substantiated by molecular genetic studies which suggested that in pigs and humans, $\mathrm{MH}$ mutations are located in the gene encoding the ryanodine receptor (RYR1) (4-7). The RYR1 is a large homotetrameric oligomer made up of four $565-\mathrm{kD}$ subunits which forms a $\mathrm{Ca}^{2+}$ channel when incorporated into lipid bilayers (8). Indeed, to date, besides the Arg615Cys point mutation, at least eight other point mutations in the RYR1 gene have been reported to cosegregate with the $\mathrm{MH}$ phenotype in human pedigrees (9-11). In this context, it should be recalled that some $\mathrm{MH}$ phenotypes do not cosegregate with the RYR1 (12-16).

So far, all known mutations in the RYR1 gene induce a hypersensitivity of biopsied muscles to $\mathrm{Ca}^{2+}$-releasing agents such as halothane, caffeine, 4-chloro- $m$-cresol, and ryanodine, and such a state is exploited in the in vitro muscle contracture test (IVCT). This test is carried out in patients with suspected or familial $\mathrm{MH}$. The procedure is highly invasive and consists of dissection and in vitro treatment of muscle fibers with increasing doses of caffeine or halothane; the resulting contracture is recorded. Individuals are then classified according to their sensitivity to both compounds, as MH-susceptible (MHS), MH-negative (MHN), or MH-equivocal, the latter nevertheless considered MHS from a clinical point of view (17).

Direct biochemical and biophysical evidence linking point mutations in the RYR1 gene to an altered functional state of the $\mathrm{Ca}^{2+}$ release channel have been scant and to date have been published only for the Arg615Cys $(18,19)$ and the Gly2434Arg point mutations (20).

This study was undertaken with the aim of studying $\mathrm{Ca}^{2+}$ homeostasis in cultured human skeletal muscle cells obtained from fragments of biopsies of patients undergoing the IVCT. We show that the hypersensitive state to triggering agents which characterizes muscle fibers of MHS individuals is maintained at the single cell level, i.e., the intracellular $\mathrm{Ca}^{2+}$ transients elicited by halothane in cells from MHS and MHN individuals differ significantly. In addition, we present evidence demonstrating that MHN- and MHS-derived primary muscle cell cultures transfected with the wild-type or mutated RYR1 (Arg163Cys) cDNAs differ significantly in their response to halothane, as far as increases in the intracellular $\mathrm{Ca}^{2+}$ concentration, $\left[\mathrm{Ca}^{2+}\right]_{i}$, are concerned. Finally, the experimental approach used in this report may be exploited in the long run to offer a less invasive but equally sensitive alternative to the IVCT. 


\section{Methods}

\section{Materials}

DME containing $4.5 \mathrm{mg} / \mathrm{ml}$ glucose, FCS, horse serum, penicillin G, streptomycin, and Lipofectin were all purchased from Life Technologies Ltd., Paisley, UK. Insulin was purchased from Eli Lilly and Company, Indianapolis, IN. Cell culture material was from Becton Dickinson $\mathrm{GmbH}$, Heidelberg, Germany. Glutamine, Hepes, fura-2/AM, anti- $\alpha$-actinin $\mathrm{mAb}$, and anti-mouse-FITC conjugates were from Sigma Chemical Co., St. Louis, MO. Indo-1 and the calcium calibration kit were from Molecular Probes, Inc., Eugene, OR. Peroxidaseconjugated protein A was from Fluka AG, Buchs, Switzerland. Immunofluorescence mounting fluid was from Difco Laboratories Inc., Detroit, MI. The Western blot chemiluminescent kit was from DuPont-NEN, Brussels, Belgium. DNA-modifying enzymes were from Boehringer Mannheim, Mannheim, Germany. Halothane was from Halocarbon Labs, Inc., Hackensack, NJ. The Bluescript cloning vector was from Stratagene Inc., La Jolla, CA. The pEGFPC3 vector was from Clontech, Palo Alto, CA. The pRLDN expression vector was a kind gift of Dr. Schatzmann, SmithKline Beecham Pharmaceuticals, King of Prussia, PA. All other chemicals were reagent or highest available grade.

\section{Patients}

Primary human muscle cell cultures obtained from five patients with a positive family history for $\mathrm{MH}$ without any clinical signs for neuromuscular diseases, sent to the MH laboratory (Kantonsspital, University of Basel) for a diagnostic muscle biopsy, were involved in this study. Muscle biopsies were taken from the vastus medialis of the quadriceps muscles under regional anesthesia using $1 \%$ mepivacain. IVCTs were performed according to the protocol of the European MH Group as described previously $(17,21)$.

\section{Human skeletal muscle cell cultures}

Sterile muscle pieces not used for IVCT, weighing between 0.5 and $2.5 \mathrm{mg}$, were taken from the biopsies; each fragment was transferred to a sterile cell culture insert within a six-well plate containing DME plus $4.5 \mathrm{mg} / \mathrm{ml}$ glucose, $20 \% \mathrm{FCS}, 5 \mathrm{ng} / \mathrm{ml}$ insulin, $200 \mathrm{mM}$ glutamine, $600 \mathrm{ng} / \mathrm{ml}$ penicillin $\mathrm{G}$ and streptomycin, and $7 \mathrm{mM}$ Hepes, $\mathrm{pH}$ 7.4. After $\sim 8-10 \mathrm{~d}$ satellite cells could clearly be seen growing attached to the insert surrounding the biopsy fragment. The culture insert was then removed, and the cells were subsequently allowed to grow onto a new tissue culture dish; the medium was changed to a differentiation medium containing $10 \%$ horse serum, $5 \mathrm{ng} / \mathrm{ml}$ insulin, $200 \mathrm{mM}$ glutamine, antibiotics, and $7 \mathrm{mM}$ Hepes, $\mathrm{pH}$ 7.4. Cell cultures were obtained from each biopsy with a success rate of $\sim 98 \%$. The protocol was approved by the University of Basel Hospital Ethics Committee. For cryopreservation, $\sim 10^{6}$ cells were preserved in DME containing $40 \%$ FCS, $10 \%$ dimethyl sulfoxide and stored in liquid nitrogen. For intracellular $\mathrm{Ca}^{2+}$ measurements and immunofluorescence studies, confluent cells were transferred and grown on glass coverslips.

\section{Genetic analysis of MHS patients}

Total RNA/DNA was extracted from muscle cells growing in small tissue culture flasks according to Chomczynski and Sacchi (22) or the salting-out method. PCR amplification of RYR1 segments was carried out using published primer sequences and amplification conditions (23-26). The presence of the Arg163Cys mutation in MHS patient 1 was confirmed by restriction enzyme digestion and singlestrand conformational polymorphism analysis as described by Quane et al. (23).

\section{Construction of the expression vectors and DNA manipulations}

The full-length rabbit skeletal muscle RYR1 cDNA was constructed as described previously (18). Replacement of $\mathrm{C}_{490}$ with $\mathrm{T}$ was performed using a cDNA cassette (EcoR1/vector-121/SalI 548) accord- ing to the method described by Kunkel et al. (27). DNA sequencing was performed by the dideoxy method of Sanger et al. (28). The wildtype and mutated (MHS Arg163Cys) RYR1 cDNAs were cloned into the pRLDN expression vector as described previously (18). Transfection of the wild-type and mutated RYR1 constructs was performed using lipofectin according to the manufacturer's instructions. To evaluate the efficiency of transfection, double transfection experiments (RYR1 cDNA constructs plus pEGFPC3 reporter vector) were performed using lipofectin.

\section{Immunological methods}

Immunofluorescence. $7 \mathrm{~d}$ after transfection, cells were used for intracellular $\mathrm{Ca}^{2+}$ measurements and subsequently fixed on the glass coverslips with an ice-cold solution of $50 \%$ methanol, $50 \%$ acetone at $-20^{\circ} \mathrm{C}$ for $20 \mathrm{~min}$. The cells were rinsed twice with PBS and preincubated for $60 \mathrm{~min}$ with $10 \%$ calf serum, $1 \%$ BSA in PBS. The cells were then incubated with an anti-RYR $1 \mathrm{mAb}$ (final concentration 20 $\mu \mathrm{g} / \mathrm{ml}$ ) raised in our laboratory, or an anti- $\alpha$-actinin $\mathrm{mAb}$ for $90 \mathrm{~min}$ at $37^{\circ} \mathrm{C}$ in TBST $(10 \mathrm{mM}$ Tris- $\mathrm{HCl}, \mathrm{pH} 8.0,150 \mathrm{mM} \mathrm{NaCl}, 0.05 \%$ Tween 20), rinsed four times with TBST, and incubated with an FITC-conjugated anti-mouse $\operatorname{IgG}$ diluted 1:50 in TBST for $60 \mathrm{~min}$ at room temperature. The coverslips were rinsed four times with TBST, mounted and examined with an inverted fluorescent microscope (Diaphot 300; Nikon Inc., Melville, NY).

Western blot analysis. $7 \mathrm{~d}$ after transfection, skeletal muscle cells were rinsed twice in PBS, scraped from the petri dishes, and homogenized in $1 \mathrm{mM}$ EDTA, $10 \mathrm{mM}$ Hepes, $\mathrm{pH}$ 7.4, $0.25 \mathrm{M}$ sucrose plus 1 $\mu \mathrm{g} / \mathrm{ml}$ leupeptin, $1 \mathrm{mM}$ PMSF, and $1 \mathrm{mM}$ benzamidine in a glass/glass potter. Nuclei were sedimented at 3,000 rpm in an Eppendorf microfuge, and the supernatant was loaded on a 5\% SDS PAGE. Protein concentration was determined according to the method of Bradford (29). Immunodetection was carried out using a mouse anti-RYR1 antibody, followed by peroxidase-conjugated protein $\mathrm{A}(1: 5,000)$ as described previously (18). Rabbit terminal cisternae microsomes were prepared from skeletal muscle as described by Saito et al. (30).

\section{$\left[\mathrm{Ca}^{2+}\right]_{i}$ ratio measurements and calibration}

The free cytosolic $\mathrm{Ca}^{2+}$ concentrations were determined in skeletal muscle cells using the fluorescent $\mathrm{Ca}^{2+}$ indicators fura- 2 or indo-1. Briefly, cells grown on glass coverslips were loaded with either $5 \mu \mathrm{M}$ fura-2/AM or $5 \mu \mathrm{M}$ indo-1/AM at $37^{\circ} \mathrm{C}$ in Krebs-Ringer solution containing $140 \mathrm{mM} \mathrm{NaCl}, 5 \mathrm{mM} \mathrm{KCl}, 1 \mathrm{mM} \mathrm{MgCl} 2,20 \mathrm{mM}$ Hepes, $1 \mathrm{mM}$ $\mathrm{NaHPO}_{4}, 5.5 \mathrm{mM}$ glucose, $1 \mathrm{mM} \mathrm{CaCl}$, pH 7.4. After $60 \mathrm{~min}$, cells were rinsed with Ringer's solution to remove unhydrolyzed indicator and stored at $20-22^{\circ} \mathrm{C}$ until used. On-line ratio measurements were recorded using a fluorescent microscope (Axiovert; Carl Zeiss $\mathrm{GmbH}$, Jena, Germeny) attached to an infrared camera (Photonic Science Ltd., Robertsbridge, UK) and analyzed using the Zeiss imaging system. Coverslips were affixed to a chamber, and experiments were performed in a thermostatically controlled atmosphere at $37^{\circ} \mathrm{C}$. 10 cells were identified in each field, and the average pixel (three frames averaged and ratioed every $3 \mathrm{~s}$ ) value for each cell was measured at excitation wavelengths of 340 and $380 \mathrm{~nm}$ at various times (fura-2 measurements). $\mathrm{Ca}^{2+}$ calibration was performed using the EGTA/ionomycin/ $\mathrm{MnCl}_{2}$ quenching method (31), and the $\left[\mathrm{Ca}^{2+}\right]$ was determined using a $K_{\mathrm{d}}$ of $225 \mathrm{nM}$ (32). Alternatively, measurements were performed using a Diaphot 300 inverted fluorescent microscope (Nikon Inc.) attached to two photomultipliers (P100; Nikon Inc.). A single cell was identified, and the average fluorescence emitted at 410 and $480 \mathrm{~nm}$ was integrated and ratioed every $50 \mathrm{~ms}$. $\mathrm{Ca}^{2+}$ calibration was performed using the cell free ratio measurement system with the $\mathrm{Ca}^{2+}$-calibration kit and a $K_{\mathrm{d}}$ of $311 \mathrm{nM}(33)$.

\section{Statistical analysis}

Statistical analysis was performed using the Student's $t$ test for paired samples and the Origin and Prism computer programs (Microcal Software, Inc., Northampton, MA, and GraphPAD Software for Science, San Diego, CA). 
Table I. IVCT of Muscle Biopsies from which Primary Cultures Were Derived

\begin{tabular}{lcccccc}
\hline & & \multicolumn{2}{c}{ Halothane } & & \multicolumn{2}{c}{ Caffeine } \\
\cline { 3 - 4 } \cline { 5 - 6 } Patient no. & Diagnosis & Threshold & Contracture* & & Threshold & Contracture \\
\hline & & $\%$ & $g$ & & $m M$ & $g$ \\
1 & MHS & 0.5 & 3.0 & & 2 & 0.2 \\
2 & MHS & 0.5 & 2.25 & & 1.5 & 0.9 \\
3 & MHN & 3.0 & 0.1 & & 0 & 0 \\
4 & MHN & 3.0 & 0.1 & & 0 & 0 \\
5 & MHN & $>3.0$ & 0 & & 0 & 0 \\
\hline
\end{tabular}

Contracture at $* 2 \%$ halothane and at $\$ 2 \mathrm{mM}$ caffeine.

\section{Results}

One of the aims of this report was to investigate whether cultured human muscle cells express differences characteristic of MHS muscles, even after several passages in culture. Table I shows the halothane- and caffeine-induced muscle contractures obtained from biopsies of the patients involved in this study and classified as MHN or MHS. Genotypic analysis indicated that MHS patient 1 carries the Arg163Cys mutation (Fig. 1), whereas in MHS patient 2, we could not detect four of the most frequent $\mathrm{MH}$ mutations.

Muscle satellite cells are small mononucleated cells present in skeletal muscle fibers which are normally quiescent but can be activated during postnatal growth, after muscle injury, or in response to intensive physical activity, after which they can proliferate and fuse (Fig. 2). To confirm that the human primary muscle cells we used in this report were indeed of skeletal muscle lineage, we performed immunofluorescence studies on glass coverslip-grown cells. The expression of skeletal muscle cytoskeletal proteins was studied using an anti- $\alpha$ sarcomeric actinin mAb. Fig. 3 shows the immunofluorescent staining of the cultured human muscle cells; regardless of whether they were obtained from biopsies of MHN $(A)$ or MHS $(B)$ patients, the pattern of fluorescence remained the same. COS-7 cells, which are not expected to express sarcomeric proteins, were negative when assayed with the anti- $\alpha$-actinin antibody $(C)$. We also studied whether the human muscle-derived cells express native SR proteins. Fig. 4 shows indirect immunofluorescence of muscle cells derived from $\mathrm{MHN}(A)$ and MHS $(B)$

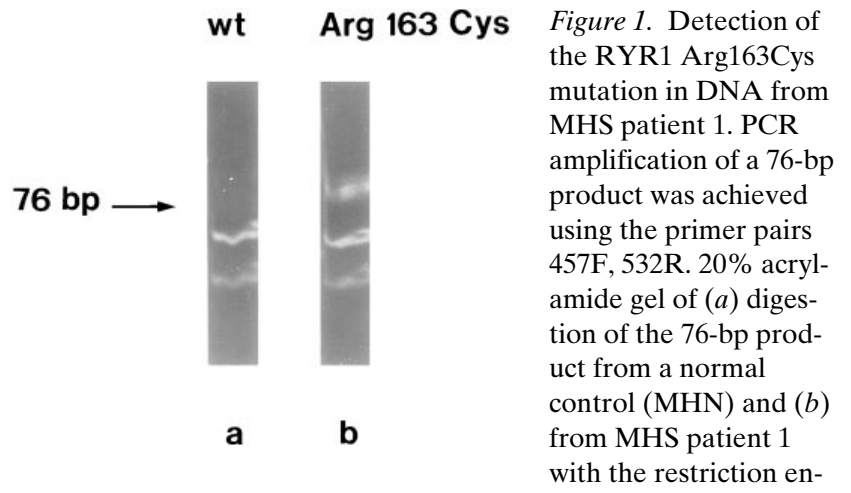

donuclease BstU1. The presence of the mutation Arg163Cys abolishes a BstU1 site. $w t$, wild-type.

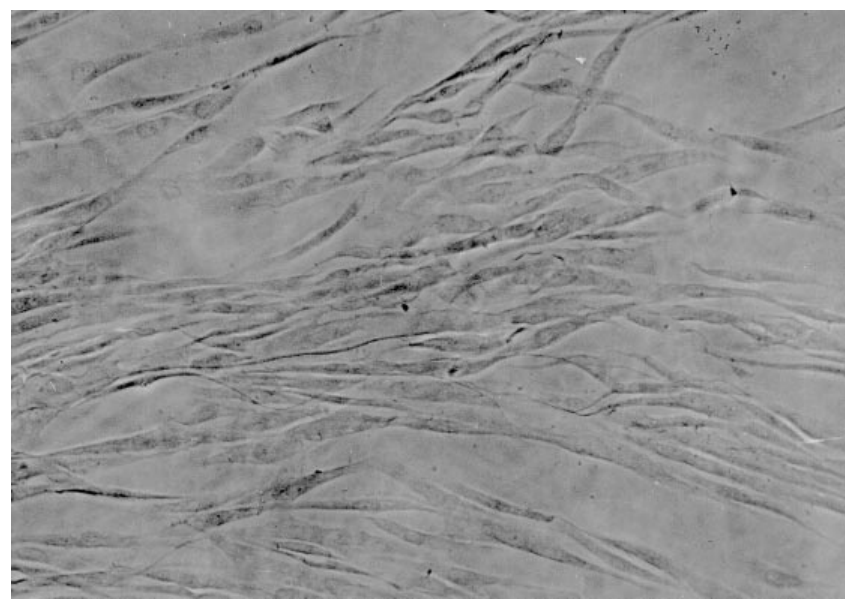

Figure 2. Phase-contrast micrograph of primary cultures derived from human skeletal muscle satellite cells $(\times 250)$. The average length $(n=20)$ of individual muscle cells was $461 \pm 2.2 \mu \mathrm{m}$.

individuals using an anti-RYR1 mAb. As shown, the fluorescent pattern appears as discreet punctuated fluorescence uniformly distributed throughout the cell. COS-7 cells, which do not express endogenous RYR1, were negative $(C)$.

Since an $\mathrm{MH}$ crisis is the result of an abnormal increase in the myoplasmic $\mathrm{Ca}^{2+}$ concentration in response to "trigger agents," we investigated intracellular $\mathrm{Ca}^{2+}$ homeostasis of muscle cells from MHN and MHS individuals. Human skeletal muscle cells were grown on glass coverslips, and single cell calcium measurements using fluorescence microscopy were performed on fura-2-loaded cells. Fig. 5 shows the single cell intracellular $\mathrm{Ca}^{2+}$ measurements of cultured muscle cells obtained from one MHN (top) and one MHS (bottom) individual. For each experiment, a total of 72 digital images were recorded at 340 and $380 \mathrm{~nm}$ and ratioed. The first image represents the resting $\left[\mathrm{Ca}^{2+}\right]_{i}$; the next two images were taken 20 and $30 \mathrm{~s}$ after perfusion with $5.7 \mathrm{mM}$ halothane; and the last image shows the fluorescence ratio after reperfusion with Krebs buffer ( $t=140 \mathrm{~s})$. As shown in Fig. 5, halothane increases substantially the myoplasmic $\left[\mathrm{Ca}^{2+}\right]$ of muscle cells derived from the MHS individual but affects only slightly that of cells derived from the MHN individual. Fig. 6 shows the actual fura-2 fluorescence ratio measurements $(340 / 380 \mathrm{~nm})$ obtained from four randomly chosen cells imaged in Fig. 5; as indicated, the addition of halothane causes an immediate increase in the fluorescence ratio of MHS-derived (solid line) but not MHNderived (dotted line) muscle cells. All experiments were performed at least three separate times on four individual MHS and MHN patients, and gave qualitatively identical results.

To evaluate in greater detail the differences between MHN- and MHS-derived muscle cells, we also performed a dose-response curve to halothane. Fig. 7 shows that the halfmaximal halothane concentration causing an increase in the fura-2 ratio was approximately two-fold lower in MHS- than in MHN-derived cells (5.8 vs. $9.5 \mathrm{mM}$, respectively).

We also studied the resting myoplasmic $\left[\mathrm{Ca}^{2+}\right]$ of skeletal muscle cells derived from MHN and MHS individuals using phototubes/photometers and the $\mathrm{Ca}^{2+}$ indicator indo- 1 . Under our experimental conditions, we did not find any significant 

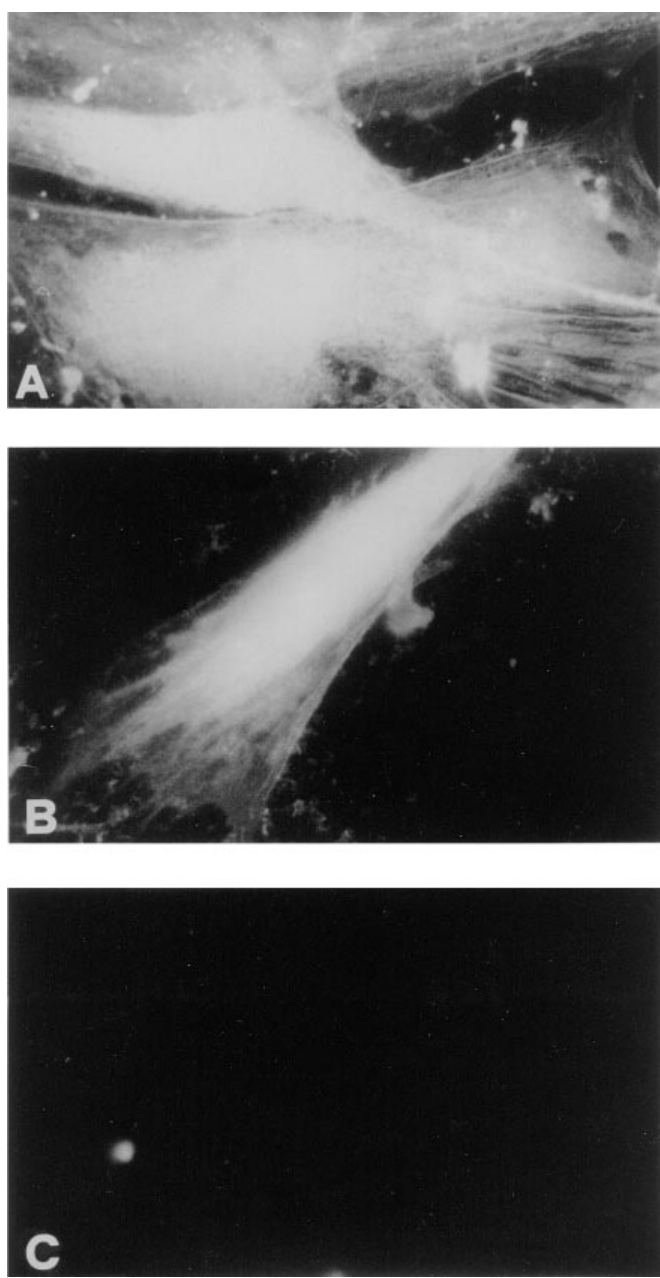

Figure 3. Indirect immunofluorescent staining for sarcomeric $\alpha$-actinin. Human skeletal muscle cells were from an MHN $(A)$ and an MHS $(B)$ individual. COS-7 cells, which do not express this marker, were negative $(C)(\times 1,500)$.

differences between the mean resting $\left[\mathrm{Ca}^{2+}\right]_{\mathrm{i}}$ of MHN or MHS cells (the mean $\left[\mathrm{Ca}^{2+}\right]_{\mathrm{i}}$ was $37.2 \pm 1.7 \mathrm{nM}, n=12$, and $40.6 \pm 2.0$ $\mathrm{nM}, n=18$, respectively).

We thought that the primary human skeletal muscle cells would offer the ideal system $(a)$ to study the effects of various point mutations found to associate with $\mathrm{MH}$, and $(b)$ to investigate whether the $\mathrm{MH}$ phenotype in cells from MHS individuals was dominant or could be reversed by the addition of wildtype RYR1 cDNA. The full-length wild-type and mutated RYR1 (RYR Arg163Cys) cDNAs were constructed and inserted into the mammalian expression vector under the control of Rous sarcoma virus long terminal repeat. Because the mutation at nucleotide 490 abolishes a BstU1 site, we used loss of this site as an analytical tool to detect the mutation (Fig. 8). Substitution of $\mathrm{T}$ for $\mathrm{C}$ was also confirmed by direct sequencing of the DNAs (not shown).

Expression of the recombinant RYR was monitored using a combination of immunocytochemical and biochemical techniques. Indirect immunofluorescence staining for the RYR in skeletal muscle cells derived from biopsies of MHN and MHS individuals revealed a uniformly distributed fluorescent pat- tern (Fig. 9, $A$ and $B$, respectively), while the fluorescent pattern of $\alpha$-actinin remained identical to that of untransfected cells (compare Fig. 10, $A$ and $B$, with fluorescent staining of cells in Fig. 3). Western blot analysis of the 3,000 $\mathrm{g}$ supernatant obtained from cells transfected either with the cDNA encoding the wild-type (Fig. 11, lane 3) or the mutated RYR1 (Fig. 11, lane 5) showed an immunopositive band having an apparent molecular weight similar to the rabbit skeletal muscle RYR (Fig 11, lane 1). An immunopositive band is also present in mock-transfected MHS- (lane 2) and MHN (lane 4)-derived cells, but appears to be more abundant in the transfected cells. The efficiency of transfection was also assessed in double transfectant muscle cells; using the reporter molecule green fluorescent protein for monitoring the degree of transfection, we found that under our conditions, $\sim 80 \%$ of the cells were
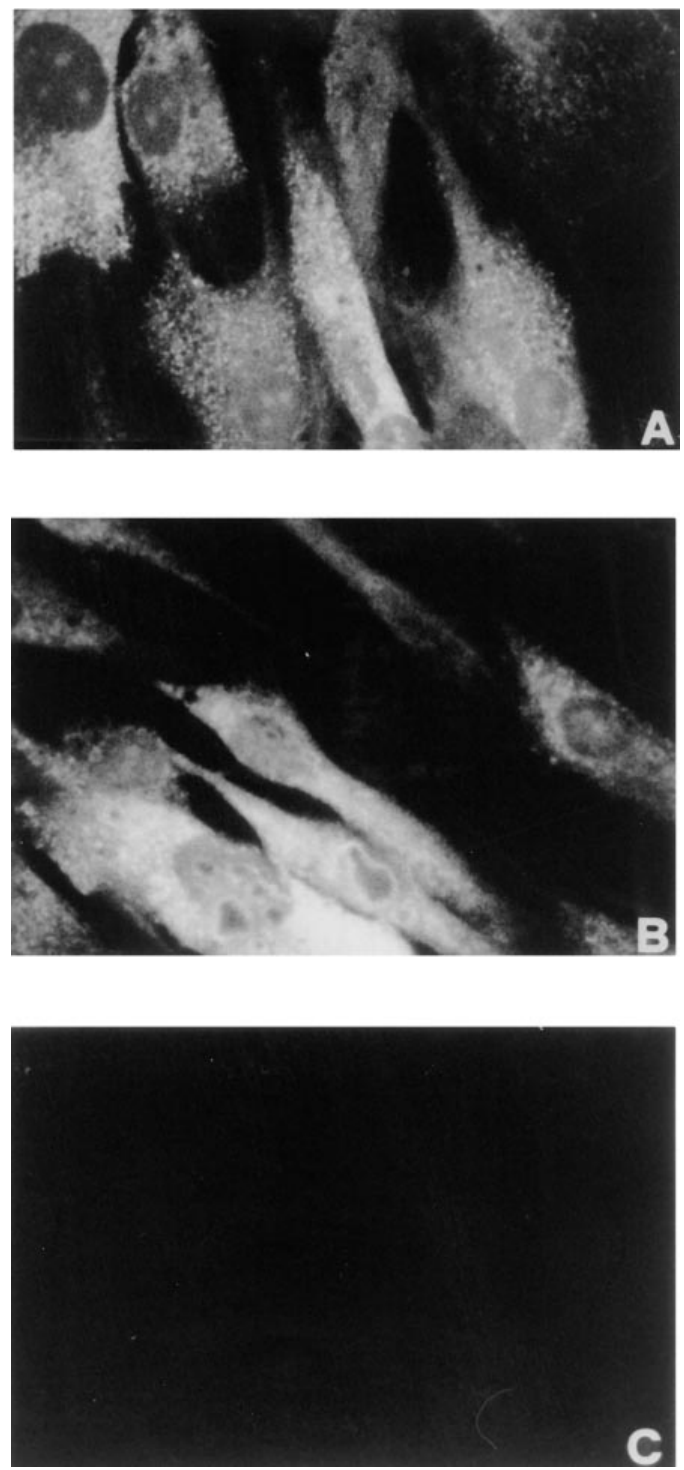

Figure 4. Indirect immunofluorescence staining for skeletal muscle RYR. Human skeletal muscle cells from $\operatorname{MHN}(A)$ and MHS $(B)$ individuals show distinct punctuated fluorescence, while COS-7 cells, which do not express the skeletal muscle RYR, are negative $(C)$ $(\times 1,500)$. 

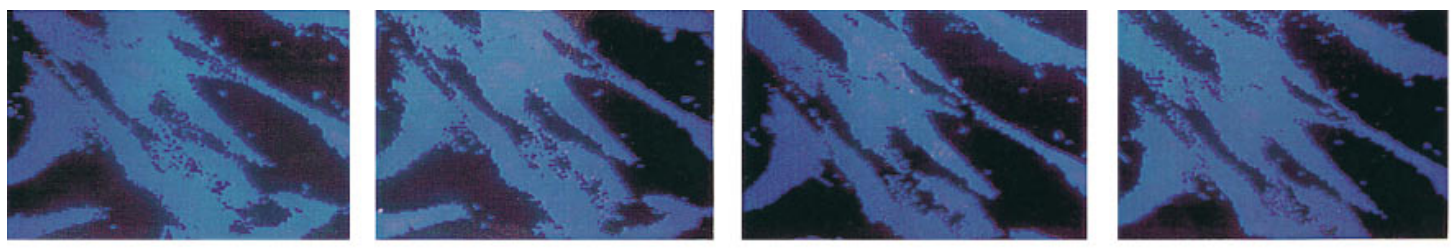

$\left[\mathrm{Ca}^{2+}\right]_{1}(\mathrm{nM})$
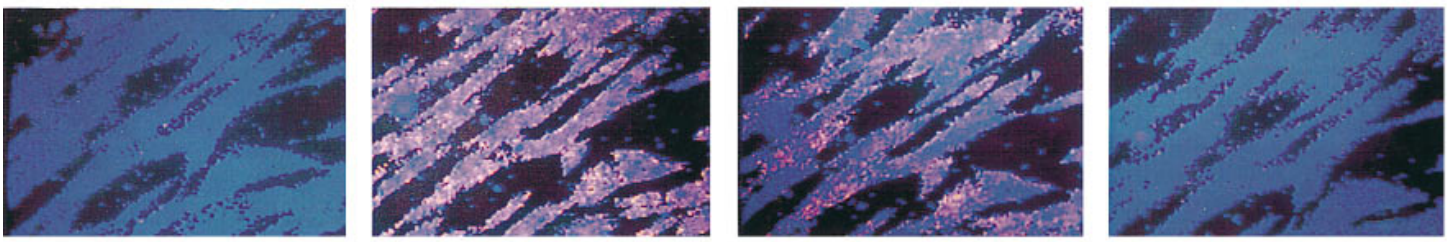

resting $\left[\mathrm{Ca}^{2+}\right]_{\mathrm{i}}$

$t=20$

$t=30$

$t=140$

Figure 5. Single cell intracellular $\mathrm{Ca}^{2+}$ measurements of cultured human skeletal muscle cells stimulated with $5.7 \mathrm{mM}$ halothane. Cells from an MHN (top) or an MHS individual (bottom) were grown on glass coverslips for $1 \mathrm{wk}$ and loaded with the fluorescent $\mathrm{Ca}^{2+}$ indicator fura-2; single cell intracellular $\mathrm{Ca}^{2+}$ measurements were performed using the Zeiss imaging system attached to an Axiovert fluorescent microscope as described in Methods. Images were taken at the indicated times after halothane addition.

transfected as demonstrated by bright green cytoplasmic fluorescence (not shown).

Thus, we studied the effect of overexpression of both wildtype and Arg163Cys mutated recombinant RYR1 cDNAs in skeletal muscle cells derived from MHS and MHN individuals. The effect of overexpression of RYR1 on intracellular $\mathrm{Ca}^{2+}$ homeostasis was evaluated by plotting the change in fluorescence ratio $(340 / 380 \mathrm{~nm})$ as a function of time after halothane addition (Fig. 12). Each trace represents the change in fluorescence ratio occurring in a single cell, and for clarity, the traces of four distinct cells are shown. Results are representative of experiments carried out at least three times in skeletal muscle cells derived from the biopsies of three MHN and two MHS

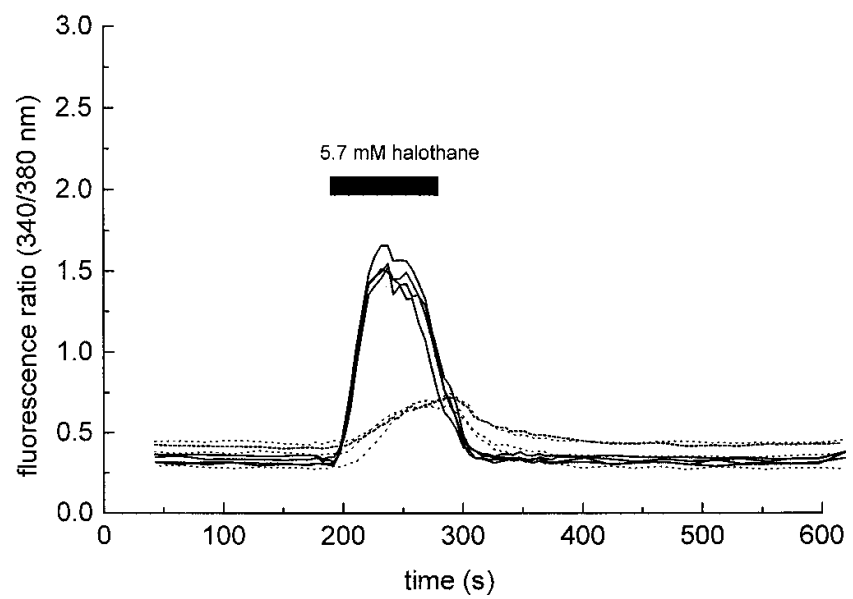

Figure 6. Halothane-induced $\mathrm{Ca}^{2+}$ responses of cultured human skeletal muscle cells. Cells were from an MHN (dotted lines) and an MHS individual (solid lines). Traces represent the changes in fluorescence ratio $(340 / 380 \mathrm{~nm})$ of four randomly chosen cells from Fig. 5. individuals. Halothane addition to MHN cells transfected with wild-type RYR evoked a calcium transient which was similar if not identical to that of mock-transfected MHN cells (Fig. 12 $A$ ). On the contrary, when the same experiment was performed on MHS-derived cells overexpressing the wild-type RYR, halothane was still capable of causing an increase in the $\left[\mathrm{Ca}^{2+}\right]$, yet to a lower extent compared with mock-transfected MHS cells (Fig. 12 B). As expected, transfection of MHNderived cells with the RYR1 cDNA carrying the Arg163Cys mutation affected dramatically the kinetics of the calcium transients. Fig. $12 C$ shows that halothane induces a very rapid and large increase in the myoplasmic $\left[\mathrm{Ca}^{2+}\right]$; in addition, it can be appreciated that the elicited calcium transient is very similar to

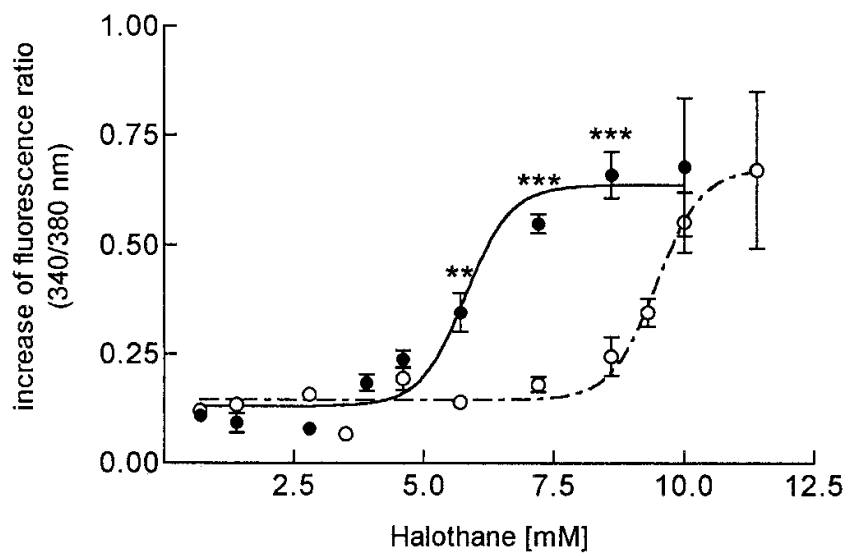

Figure 7. Dose-response curve to halothane. $\left[\mathrm{Ca}^{2+}\right]_{\mathrm{i}}$ measurements were carried out as described in Fig. 5. Values represent the mean $\pm \operatorname{SEM}(n=10)$ increase in fura-2 fluorescence ratio $(340 / 380$ $\mathrm{nm})$. $* * P<0.01 ; * * * P<0.001$. 

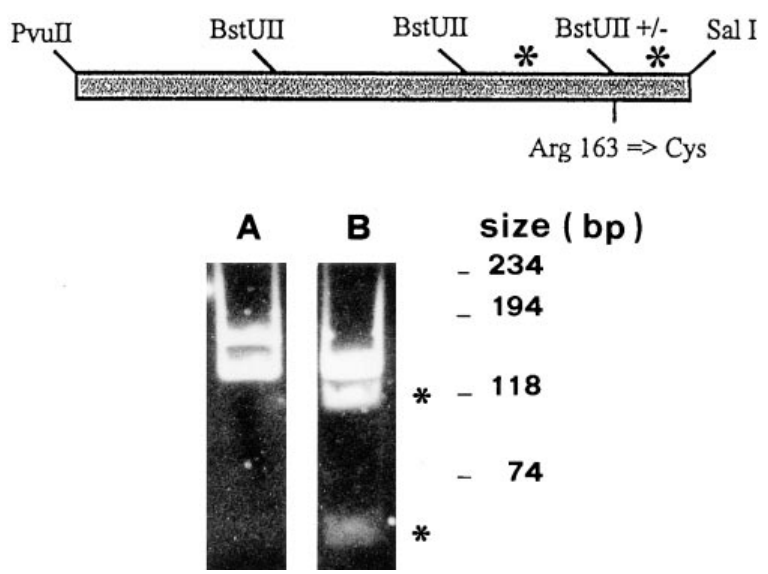

Figure 8. BstU1 restriction endonuclease digestion of the RYR1 PvuII 96-Sal1 546-bp cDNA fragment. Lane 1, RYR1 cDNA carrying the Arg163Cys point mutation; lane 2, wild-type RYR1. *The bands of 120 and $54 \mathrm{bp}$ which are replaced by a band of $174 \mathrm{bp}$ in the mutated RYR cDNA. The other two fragments of 144 and $146 \mathrm{bp} \mathrm{mi-}$ grated as a single band (top) in this gel.

that exhibited by mock-transfected MHS cells. Fig. 13 compares the average (mean \pm SEM) peak in the $\left[\mathrm{Ca}^{2+}\right]_{\mathrm{i}}$ induced in RYR1 wild-type/Arg163Cys mutated cDNA-transfected or mock-transfected skeletal muscle cells from MHN and MHS individuals. Overexpression of the wild-type RYR1 cDNA in MHS-derived cells caused a significant decrease $(\sim 50 \%)$ in
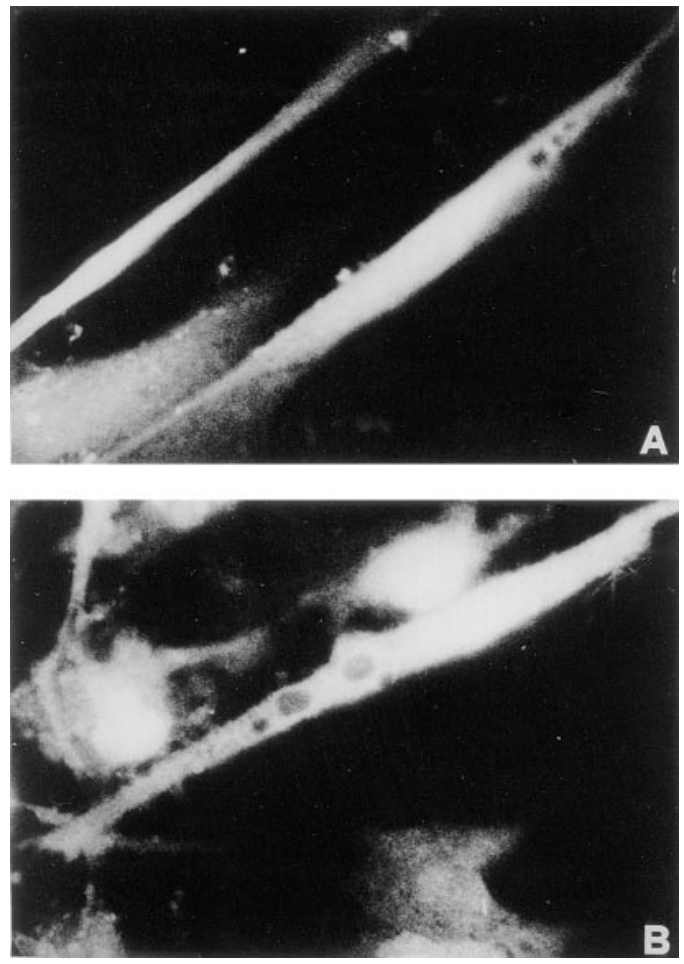

Figure 9. Indirect immunofluorescent staining for skeletal muscle RYR in human skeletal muscle cells overexpressing RYR1. Cells from MHN $(A)$ and MHS $(B)$ individuals were transfected with the RYR1 cDNA carrying the $\operatorname{Arg} 163$ Cys point mutation $(A)$ or the wild-type RYR cDNA $(B)$, as detailed in Methods $(\times 1,500)$.
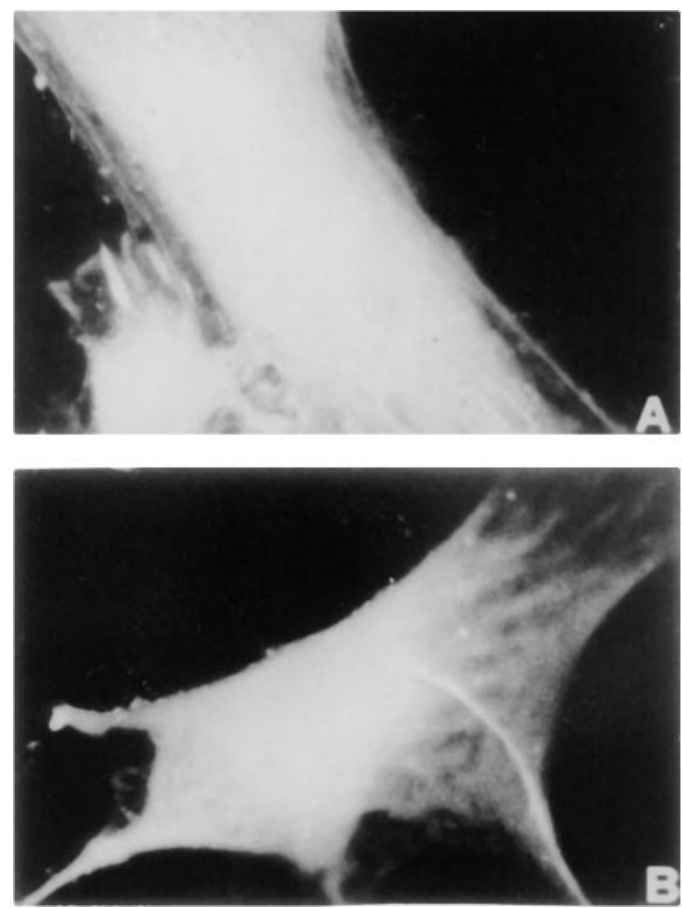

Figure 10. Indirect immunofluorescent staining for sarcomeric $\alpha$-actinin in human skeletal muscle cells overexpressing RYR1. Cells from an MHN individual were transfected with the RYR1 cDNA carrying the Arg163Cys point mutation $(A)$; cells from an MHS individual were transfected with the wild-type RYR1 cDNA $(B)$. Overexpression of the RYR does not affect the fluorescent pattern for sarcomeric $\alpha$-actinin $(\times 1,500)$.

the peak $\left[\mathrm{Ca}^{2+}\right]_{\mathrm{i}}$ induced by halothane; however, overexpression of a channel carrying the Arg163Cys point mutation in muscle cells derived from an MHN individual caused a fourfold increase in the peak $\left[\mathrm{Ca}^{2+}\right]_{\mathrm{i}}$ induced by halothane. Over-

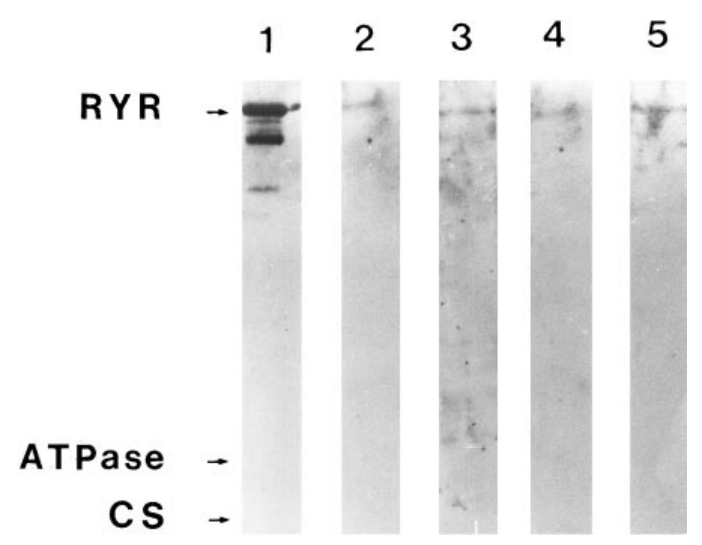

Figure 11. Western blot analysis of human skeletal muscle cells transfected with the cDNA encoding RYR1. Lane $1,15 \mu \mathrm{g}$ rabbit skeletal muscle terminal cisternae; lanes 2 and 4,3,000 rpm supernatant of mock-transfected MHS and MHN skeletal muscle cells; lane 3, 3,000 rpm supernatant of MHS cells transfected with the wild-type RYR1 cDNA; lane 5, 3,000 rpm supernatant of MHN cells transfected with the RYR1 cDNA carrying the Arg163Cys point mutation $(80 \mu \mathrm{g}$ protein loaded per lane). Arrows, The RYR (565 kD), the $\mathrm{Ca}^{2+}$ ATPase $(110 \mathrm{kD})$, and calsequestrin $(65 \mathrm{kD})$. 

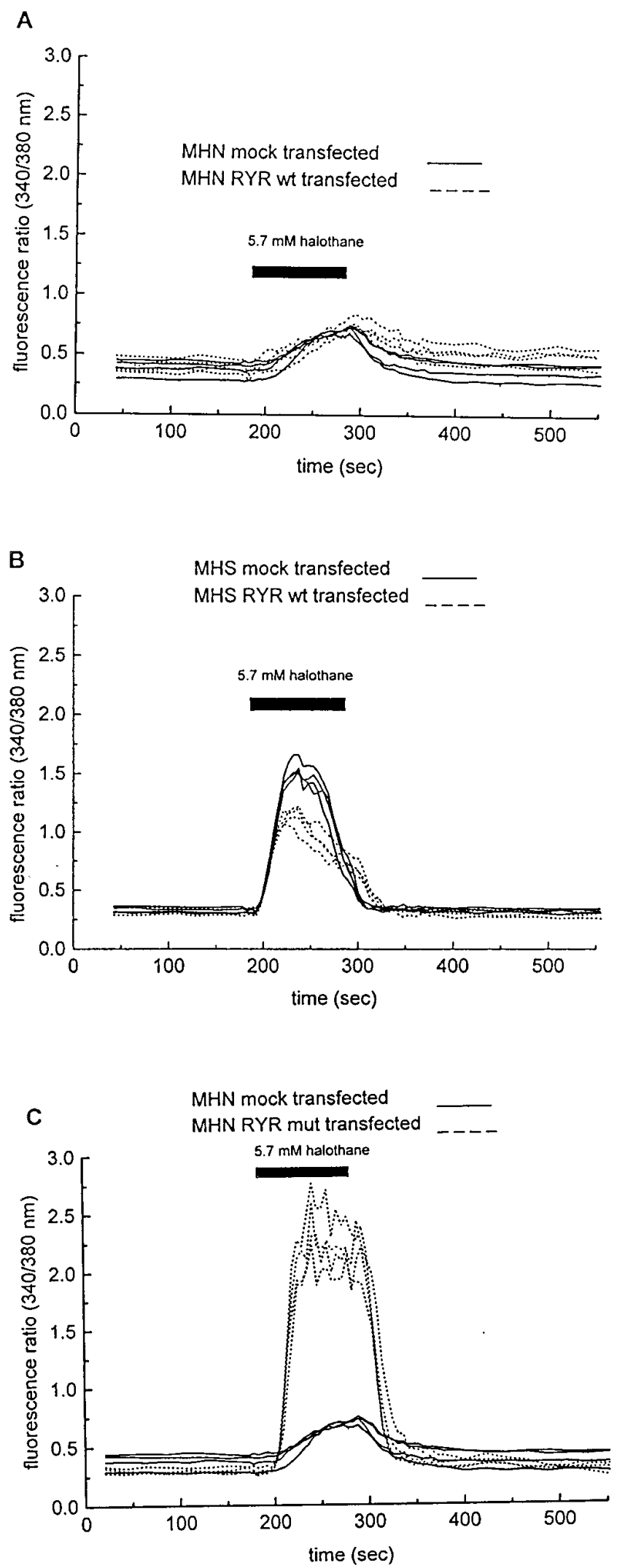

Figure 12. Halothane-induced $\mathrm{Ca}^{2+}$ responses of cultured human skeletal muscle cells. Mock-transfected cells (solid lines) and RYR1 cDNA-transfected cells (dotted lines). (A) Cells from an MHN patient transfected with wild-type RYR1 cDNA; $(B)$ cells from an MHS patient transfected with wild-type RYR1 cDNA; $(C)$ cells from an

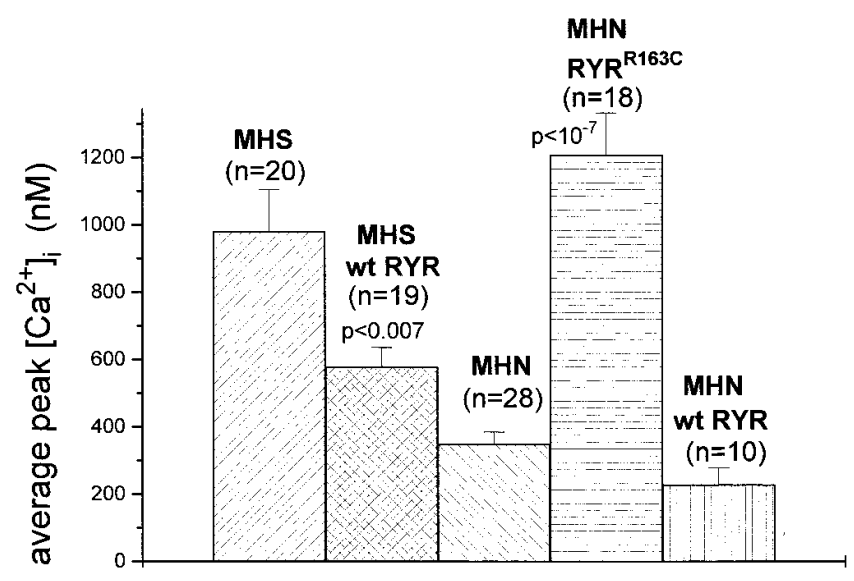

Figure 13. Average peak $\left[\mathrm{Ca}^{2+}\right]_{\mathrm{i}}$ induced by $5.7 \mathrm{mM}$ halothane in mock-transfected or RYR1 cDNA-transfected human skeletal muscle cells. Results are the mean \pm SEM of $n$ cells. $w t$, wild-type.

expression of the wild-type RYR1 cDNA in MHN-derived cells did not change significantly the peak $\left[\mathrm{Ca}^{2+}\right]_{i}$ induced by halothane.

The halothane dose-response curves in Fig. 14 show that the transfection of MHN cells with Arg163Cys RYR1 cDNA decreases approximately twofold the half-maximal halothane concentration necessary to cause an increase in the fluorescence ratio of fura-2 (4.9 vs. $9.5 \mathrm{mM}$ for Arg163Cys RYR1 cDNA- and mock-transfected cells, respectively). On the other hand, the half-maximal halothane concentration necessary to increase the fura- 2 ratio of MHS cells transfected with the wild-type RYR1 cDNA was higher than that of MHS mock-transfected cells (6.9 vs. $5.8 \mathrm{mM}$, respectively), but lower than that of MHN mock-transfected cells. The latter result indicates that the presence of altered $\mathrm{Ca}^{2+}$ release channels is sufficient to convey halothane hypersensitivity to skeletal muscle cells.

\section{Discussion}

Satellite cells give rise to a heterogeneous population of cells which can undergo differentiation into myoblasts and myotubes under appropriate culture conditions. In the past few years, several reports have appeared concerning the biochemical characterization of satellite cell-derived skeletal muscle cell cultures $(34,35)$ : as far as the expression of cytoskeletal proteins and proliferative capacity are concerned, numerous species-specific differences exist (36). Cells obtained from human biopsies appear to have undergone some sort of differentiation step towards the skeletal muscle phenotype, and express skeletal muscle-specific cytoskeletal proteins (37).

One of the major objectives of this report was to evaluate the feasibility of substituting the IVCT with $\mathrm{Ca}^{2+}$-imaging

MHN individual transfected with RYR1 cDNA containing the Arg163Cys point mutation. Traces represent the changes in fluorescence ratio $(340 / 380 \mathrm{~nm})$ of four randomly chosen cells which had been either mock-transfected or transfected with the appropriate RYR1 cDNA construct. Conditions as described in Fig. 5. 


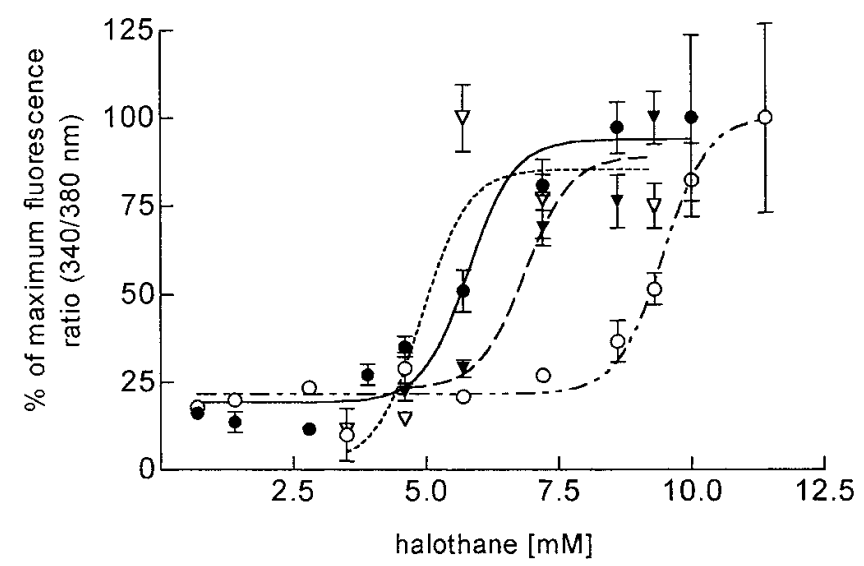

Figure 14. Halothane dose-response curve in MHN and MHS cells transfected with RYR1 cDNA constructs. Conditions as described in Fig. 7. Results are expressed as mean $\pm \operatorname{SEM}(n=10)$ percent fluorescence increase. $100 \%$ was the maximal fluorescence ratio increase induced by the highest halothane concentration. Filled circle, solid line, MHS. Open circle, uneven lines, MHN. Open triangle, dotted line, MHN RYR mutated. Filled triangle, dashed line, MHS RYR wildtype.

studies on primary cultures of human skeletal muscle-derived cells. So far, we have obtained primary cultures from the tested biopsies with a very high efficiency, and positive IVCT contracture tests have correlated well (correlation coefficient $=$ $0.88, P=0.0192$ ) with an increased halothane sensitivity of cultured skeletal muscle cells (38). In these experiments, we used millimolar halothane concentrations. We are aware that clinically used halothane concentrations are $<1 \mathrm{mM}$, and that the threshold concentration for abnormal muscle contractures in the IVCT is $0.44 \mathrm{mM}$ halothane. Nevertheless, there are reasons that may account for using higher concentrations of halothane in our experiments: $(a)$ a cell culture model has general differences compared with the in vivo situation; $(b)$ it is interesting that Otsu et al. (19) have used a $5.7 \mathrm{mM}$ halothane concentration to demonstrate differences in the effects of halothane on $\left[\mathrm{Ca}^{2+}\right]_{\mathrm{i}}$ between wild-type and Arg615Cystransfected $\mathrm{C}_{2} \mathrm{C}_{12}$ cells; $(c)$ when we performed experiments using low doses of halothane $(<2 \mathrm{mM})$, we did not observe significant increases in the $\left[\mathrm{Ca}^{2+}\right]_{\mathrm{i}}$ in cells derived from either MHS or MHN individuals; $(d)$ a halothane dose-response curve shows that the effect of halothane on the $\left[\mathrm{Ca}^{2+}\right]_{i}$ of MHN- and MHS-derived cells is saturable; and $(e)$ we are able to clearly demonstrate a significant difference in the $\mathrm{EC}_{50}$ to halothane between MHS and MHN human muscle cells. Moreover, it is possible that these high doses of halothane may also inhibit the SR CaATPase (39), and thus unmask the release of $\mathrm{Ca}^{2+}$ from intracellular stores which is higher in MHS than MHN cells.

The RYR mediates $\mathrm{Ca}^{2+}$ release from the SR. The primary structure of the skeletal muscle RYR has been deduced from the cDNA of several species: the carboxy-terminal segment contains the hydrophobic pore-forming region, while the remaining $70-80 \%$ of the molecule forms a large hydrophilic region which has been assigned to the cytoplasmic side of the SR $(40,41)$. Though in humans, $\mathrm{MH}$ is a heterogeneous genetic disorder (12-16), all known mutations in the RYR1 cDNA have been mapped to the large hydrophilic amino-terminal portion of the molecule, and it has been assumed that they cause functional alterations in the $\mathrm{Ca}^{2+}$ release properties of the RYR. In this study, we show for the first time that the transfection of human skeletal muscle cells with the cDNA encoding the mutated RYR1 Arg163Cys and subsequent challenge with halothane cause a twofold decrease in the $\mathrm{EC}_{50}$ for halothane, thus supporting the hypothesis that at least some mutations associated with $\mathrm{MH}$ lead to an increase in the rate of $\mathrm{Ca}^{2+}$ release from the SR (42).

As to the overexpression of wild-type RYR1 in skeletal muscle cells from MHS individuals, the situation is more complex; under our experimental conditions, the hypersensitivity to halothane which characterizes MHS was reverted only partially by transfection of muscle cells with the wild-type RYR1 cDNA, and halothane was still capable of causing an increase in $\left[\mathrm{Ca}^{2+}\right]_{i}$, though to a significantly lower extent. Thus, it seems that the defective ( $\mathrm{MH}$ mutated) channels maintain their hypersensitive state to $\mathrm{MH}$-triggering agents regardless of the overexpression of wild-type channels. These results support and extend previous studies (43) which indicated that a single defective subunit in the tetrameric channel is sufficient to confer the MH phenotype.

One of the most frequent yet unresolved questions concerning $\mathrm{MH}$ is whether the resting myoplasmic $\left[\mathrm{Ca}^{2+}\right]$ of the muscle cells from MHS individuals is significantly different from that of MHN individuals $(44,45)$. Indeed, evidence in favor of this hypothesis has been gathered mainly using $\mathrm{Ca}^{2+}$ electrodes. Though sensitive, the main drawback of this approach is that it damages the muscle fiber, causing leakage of ions into the myoplasm. In fact, other investigators (46) have reported that the resting $\mathrm{Ca}^{2+}$ levels in muscle fibers from MHN and MHS swine are not significantly different, a result supported by these findings. In terms of free $\mathrm{Ca}^{2+}$, we found that the cytoplasmic concentration was much lower than that reported by Benders et al. (47) for human cultured skeletal muscle cells (35-40 $\mathrm{nM}$ in this report vs. $125 \mathrm{nM}$ in reference 47), but similar to that reported for resting mouse cultured skeletal muscle cells (48). However we would like to point out that $(a)$ we obtained identical results using two different $\mathrm{Ca}^{2+}$ indicators and two distinct methodologies; $(b)$ it is a wellestablished fact that the use of fluorescent $\mathrm{Ca}^{2+}$ indicators does not give exact quantitative values; $(c)$ the $K_{\mathrm{d}}$ of $\mathrm{Ca}^{2+}$ indicators is obtained in solution and may vary somewhat within the cytoplasm (49); and $(d)$ though the values may be altered in quantitative terms, they are not affected qualitatively; thus, though the mean resting $\left[\mathrm{Ca}^{2+}\right]$ may be underestimated, this occurs for both MHS and MHN cells. At any given time, the mean resting myoplasmic $\mathrm{Ca}^{2+}$ concentration is the net between efflux from the SR and activity of the $\mathrm{Ca}^{2+}$-extrusion mechanisms. If $\mathrm{MH}$ is characterized by an increased rate of $\mathrm{Ca}^{2+}$ release, i.e., an increase in $\mathrm{Ca}^{2+}$ leakage from the SR via the RYR1, one might expect the resting myoplasmic $\left[\mathrm{Ca}^{2+}\right]$ to be higher in MHS individuals; however, the $\mathrm{Ca}^{2+}$-extrusions systems are capable of compensating for the increased leakage by increasing their activity so that the result is an unaltered resting free $\mathrm{Ca}^{2+}$ concentration.

The use of skeletal muscle primary cultures seems to be the ideal tool to study the physiology and biochemistry of cells isolated from $\mathrm{MH}$-equivocal individuals and the effects on intracellular $\mathrm{Ca}^{2+}$ homeostasis of other point mutations genotypi- 
cally linked to $\mathrm{MH}$, as well as the effects of newly developed drugs.

\section{Acknowledgments}

We would like to thank Esther Schmid for performing the cell cultures and Stefano Forti for performing single-strand conformational polymorphism analysis.

This work was supported by grants from Telethon Italy to S. Treves (project 908), from the Swiss National Foundation (grant 3247176.96), Ministero dell'Università e della Ricerca Scientifica e Tecnologica 40 and $60 \%$ to F. Zorzato, and the Anesthesia Department of Basel University Hospital.

\section{References}

1. Denborough, M.A., and R.R.H. Lovell. 1960. Anaesthetic deaths in a family. Lancet. 2:45.

2. MacLennan, D.H., and M.S. Phillips. 1992. Malignant hyperthermia. Science. 256:789-794.

3. Mickelson, J.R., E.M. Gallant, L.A. Litterer, K.M. Johnson, W.E. Rempel, and C.F. Louis. 1988. Abnormal sarcoplasmic reticulum ryanodine receptor in malignant hyperthermia. J. Biol. Chem. 263:9310-9315.

4. MacLennan, D.H., C. Duff, F. Zorzato, J. Fujii, M. Phillips, R.G. Korneluk, W. Frodis, B.A. Britt, and R.G. Worton. 1990. Ryanodine receptor gene is a candidate for predisposition to malignant hyperthermia. Nature. 343:559561.

5. McCarthy, T.V., J.M.S. Healy, J.J.A. Heffron, M. Lehane, T. Deufel, F. Lehmann-Horn, M. Farrall, and K. Johnson. 1990. Localization of the malignant hyperthermia susceptibility locus to human chromosome $19 \mathrm{q} 12-13.2$. Nature. 343:562-564.

6. Fujii, J., K. Otsu, F. Zorzato, S. de Leon, V.K. Khanna, J.E. Weiler, P.J. O'Brien, and D.H. MacLennan. 1991. Identification of a mutation in porcine ryanodine receptor associated with malignant hyperthermia. Science. 253:448451.

7. Gillard, E.F., K. Otsu, J. Fujii, V.K. Khanna, S. de Leon, J. Derdemezi, B.A. Britt, C.L. Duff, R.G. Worton, and D.H. MacLennan. 1991. A substitution of cysteine for arginine 614 in the ryanodine receptor is potentially causative of human malignant hyperthermia. Genomics. 11:751-755.

8. Smith, J.S., R. Coronado, and G. Meissner. 1986. Single channel measurements of the calcium release channel from skeletal muscle sarcoplasmic reticulum. Activation by $\mathrm{Ca}^{2+}$ and ATP and modulation by $\mathrm{Mg}^{2+}$. J. Gen. Physiol. 88:573-588.

9. Mickelson, J.R., and C.F. Louis. 1996. Malignant hyperthermia: excitation-contraction coupling, $\mathrm{Ca}^{2+}$ release channel, and cell $\mathrm{Ca}^{2+}$ regulation defects. Physiol. Rev. 76:537-591.

10. Keating, K.E., L. Giblin, P.J. Lynch, K.A. Quane, M. Lehane, J.J.A. Heffron, and T.V. McCarthy. 1997. Detection of a novel mutation in the ryanodine receptor gene in an Irish malignant hyperthermia pedigree: correlation of the IVCT response with the affected and unaffected haplotypes. J. Med. Genet. 34:291-296.

11. Lynch, P.J., R. Krivosic-Horber, H. Reyford, N. Monnier, K. Quane, P. Adnet, G. Haudecoeur, I. Krivosic., T. McCarthy, and J. Lunardi. 1997. Identification of heterozygous and homozygous individuals with the novel RYR1 mutation Cys35Arg in a large kindred. Anesthesiology (Hagerst.). 86:620-626.

12. Levitt, R.C., N. Nouri, A.E. Jedlicka, V.A. McKusick, A.R. Marks, J.G. Shutack, J.E. Fletcher, H. Rosenberg, and D.A. Meyers. 1991. Evidence for genetic heterogeneity in malignant hyperthermia susceptibility. Genomics. 11: 543-547.

13. Levitt, R.C., A. Olckers, S. Meyers, J.E. Fletcher, H. Rosenberg, H. Isaacs, and D.A. Meyers. 1992. Evidence for the localization of a malignant hyperthermia susceptibility locus (MHS2) to human chromosome 17q. Genomics. 14:562-566.

14. Iles, D.E., F. Lehmann-Horn, S.W. Scherer, L.-C. Tsui, D.O. Weghuis, R.F. Suijkerbuijk, L. Heytens, G. Mikala, A. Schwartz, F.R. Ellis, et al. 1994. Localization of the gene encoding the a2/d-subunits of the L-type voltagedependent calcium channel to chromosome $7 \mathrm{q}$ and analysis of the segregation of flanking markers in malignant hyperthermia susceptible families. Hum. Mol. Genet. 3:969-975.

15. Sudbrak, R., V. Procacco, M. Klausnitzer, J.L. Curran, K. Monsieurs, C. van Broeckhoven, R. Ellis, L. Heytens, E.J. Hartung, G. Kozak-Ribbens, et al. 1995. Mapping of a further malignant hyperthermia susceptibility locus to chromosome 3q13.1. Am. J. Hum. Genet. 56:684-691.

16. Deufel, T., A. Golla, D. Iles, A. Meindl, T. Meitinger, D. Schindelhauer, A. DeVries, D. Pongratz, D.H. MacLennan, K.J. Johnson, and F. LehmannHorn. 1992. Evidence for genetic heterogeneity of malignant hyperthermia susceptibility. Am. J. Hum. Genet. 50:1151-1161.
17. 1984. A protocol for the investigation of malignant hyperpyrexia (MH) susceptibility. The European Malignant Hyperpyrexia Group. Br. J. Anaesth. $56: 1267-1269$.

18. Treves, S., F. Larini, P. Menegazzi, T.H. Steinberg, M. Koval, B. Vilsen, J.P. Andersen, and F. Zorzato. 1994. Alteration of intracellular $\mathrm{Ca}^{2+}$ transients in COS-7 cells transfected with the cDNA encoding skeletal-muscle ryanodine receptor carrying a mutation associated with malignant hyperthermia. Biochem. J. 301:661-665.

19. Otsu, K., Y. Nishida, K. Kimura, T. Kuzuya, M. Hori, T. Kamada, and M. Tada. 1994. The point mutation Arg615 $\rightarrow$ Cys in $\mathrm{Ca}^{2+}$ release channel of skeletal sarcoplasmic reticulum is responsible for hypersensitivity to caffeine and halothane in malignant hyperthermia. J. Biol. Chem. 269:9413-9415.

20. Richter, M., L. Schleithoff, T. Deufel, F. Lehmann-Horn, and A. Herrmann-Frank. 1997. Functional characterization of a distinct ryanodine receptor mutation in malignant hyperthermia-susceptible muscle. J. Biol. Chem. 272: 5256-5260.

21. Urwyler, A., K. Censier, M.A. Kaufmann, and J. Drewe. 1994. Genetic effects on the variability of the halothane and caffeine muscle contracture tests. Anesthesiology (Hagerst.). 80:1287-1295.

22. Chomczynski, P., and N. Sacchi. 1987. Single-step method of RNA isolation by acid guanidinium thiocyanate-phenol-chloroform extraction. Anal. Biochem. 162:156-159.

23. Quane, K.A., J.M.S. Healy, K.E. Keating, B.M. Manning, F.J. Couch, L.M. Palmucci, C. Doriguzzi, T.H. Fagerlund, K. Berg, H. Ording, et al. 1993 Mutations in the ryanodine receptor gene in central core disease and malignant hyperthermia. Nat. Genet. 5:51-55.

24. Keating, K.E., K.A. Quane, B.M. Manning, M. Lehane, E. Hartung, K. Censier, A. Urwyler, M. Klausnitzer, C.R. Muller, J.J.A. Heffron, and T.V. McCarthy. 1994. Detection of a novel RYR1 mutation in four malignant hyperthermia pedigrees. Hum. Mol. Genet. 3:1855-1858.

25. Quane, K.A., K.E. Keating, B.M. Manning, J.M.S. Healy, K. Monsieurs, J.J.A. Heffron, M. Lehane, L. Heytens, R. Krivosic-Horber, P. Adnet, et al. 1994. Detection of a novel common mutation in the ryanodine receptor gene in malignant hyperthermia: implications for diagnosis and heterogeneity studies. Hum. Mol. Genet. 3:471-476.

26. Otsu, K., M.S. Phillips, V.J. Khanna, S. de Leon, and D.H. MacLennan. 1992. Refinement of diagnostic assays for a probable causal mutation for porcine and human malignant hyperthermia. Genomics. 13:835-837.

27. Kunkel, T.A., J.D. Roberts, and R.A. Zakour. 1987. Rapid and efficient site-specific mutagenesis without phenotypic selection. Methods Enzymol. 154: 367-390.

28. Sanger, F., S. Nicklen, and A.R. Coulson. 1977. DNA sequencing with chain-terminating inhibitors. Proc. Natl. Acad. Sci. USA. 74:5463-5467.

29. Bradford, M.M. 1976. A rapid and sensitive method for the quantitation of microgram quantities of protein utilizing the principle of protein-dye binding. Anal. Biochem. 72:248-254.

30. Saito, A., S. Seiler, A. Chu, and S. Fleischer. 1984. Preparation and morphology of sarcoplasmic reticulum terminal cisternae from rabbit skeletal muscle. J. Cell Biol. 99:875-885.

31. Thomas, A.P., and F. Delaville. 1991. The use of fluorescent indicators for measurements of cytosolic-free calcium concentration in cell populations and single cells. In Cellular Calcium. J.G. McCormack and P.H. Cobbold, editors. Oxford University Press, New York. 1-54.

32. Grynkiewicz, G., M. Poenie, and R.Y. Tsien. 1985. A new generation of $\mathrm{Ca}^{2+}$ indicators with greatly improved fluorescence properties. J. Biol. Chem. 260:3440-3450.

33. Westerblad, H., and D.G. Allen. 1996. Intracellular calibration of the calcium indicator indo-1 in isolated fibers of Xenopus muscle. Biophys. J. 71: 908-917.

34. Yasin, R., G. Van Beers, K.C.E. Nurse, S. Al-Ani, D.N. Landon, and E.J. Thompson. 1977. A quantitative technique for growing human adult skeletal muscle in culture starting from mononucleated cells. J. Neurol. Sci. 32:347359

35. Zuurveld, J.G.E.M., A. Oosterhof, J.H. Veerkamp, and H.T.B. van Moerkerk. 1985. Oxidative metabolism of cultured human skeletal muscle cells in comparison with biopsy material. Biochim. Biophys. Acta. 844:1-8.

36. Allen, R.E., L.L. Rankin, E.A. Greene, L.K. Boxhorn, S.E. Johnson, R.G. Taylor, and P.R. Pierce. 1991. Desmin is present in proliferating rat muscle satellite cells but not in bovine muscle satellite cells. J. Cell. Physiol. 149: 525-535.

37. Blau, H.M., and C. Webster. 1981. Isolation and characterization of human muscle cells. Proc. Natl. Acad. Sci. USA. 78:5623-5627.

38. Censier, K., M.D. Sigg, and A. Urwyler. 1997. Altered calcium control mechanism in myotubes from subjects with malignant hyperthermia. Anesthesiology (Hagerst.). 87:A966. (Abstr.)

39. Blank, T.J.J., R. Gruener, S.L. Suffecool, and M. Thompson. 1981. Calcium uptake by isolated sarcoplasmic reticulum: examination of halothane inhibition, $\mathrm{pH}$ dependence and $\mathrm{Ca}^{2+}$ dependence of normal and malignant hyperthermic human muscle. Anesth. Analg. 160:492-498.

40. Fleischer, S., and M. Inui. 1989. Biochemistry and biophysics of excitation contraction coupling. Annu. Rev. Biophys. Biophys. Chem. 18:333-364.

41. Sutko, J.L., and J.A. Airey. 1996. Ryanodine receptor $\mathrm{Ca}^{2+}$ release 
channels: does diversity in form equal diversity in function? Physiol. Rev. 76: 1027-1071.

42. Shomer, N.H., J.R. Mickelson, and C.F. Louis. 1994. Caffeine stimulation of malignant hyperthermia-susceptible sarcoplasmic reticulum $\mathrm{Ca}^{2+}$ release channel. Am. J. Physiol. 267:C1253-C1261.

43. Valdivia, H.H., K. Hogan, and R. Coronado. 1991. Altered binding site for $\mathrm{Ca}^{2+}$ in the ryanodine receptor of human malignant hyperthermia. Am. J. Physiol. 261:C237-C245.

44. Lopez, J.R., L. Alamo, C. Caputo, J. Wikinski, and D. Ledezma. 1985. Intracellular ionized calcium concentration in muscles from humans with malignant hyperthermia. Muscle Nerve. 8:355-358.

45. Lopez, J.R., A. Gerardi, M.J. Lopez, and P.D. Allen. 1992. Effects of dantrolene on myoplasmic free $\left[\mathrm{Ca}^{2+}\right]$ measured in vivo in patients susceptible to malignant hyperthermia. Anesthesiology (Hagerst.). 76:711-719.
46. Iaizzo, P.A., W. Klein, and F. Lehmann-Horn. 1988. Fura-2 detected myoplasmic calcium and its correlation with contracture force in skeletal muscle from normal and malignant hyperthermia susceptible pigs. Pflügers Arch. 411:648-653.

47. Benders, A.G.M., A. Oosterhof, R.A. Wevers, and J.H. Veerkamp. 1997. Excitation-contraction coupling of cultured human skeletal muscle cells and the relation between basal cytosolic $\mathrm{Ca}^{2+}$ and excitability. Cell Calcium. 21: 81-91.

48. Allen, D.G., and H. Westerbland. 1995. The effects of caffeine on intracellular calcium, force and the rate of relaxation of mouse skeletal muscle. $J$. Physiol. 487:331-342.

49. Bassani, J.W.M., R.A. Bassani, and D.M. Bers. 1995. Calibration of indo- 1 and resting intracellular $\mathrm{Ca}^{2+}$ in intact rabbit cardiac myocytes. Biophys. J. $68: 1453-1460$ 